\title{
Assessing How Bankruptcy Prediction Models Are Evaluated
}

Jeffry R. Haber, (E-mail: jhaber@iona.edu), Iona College

\begin{abstract}
Since bankruptcy prediction became a popular research topic in the mid-1960s the model used for evaluating the research has remained largely unchanged. A matched-pair sample design combined with a dichotomous classification test has been the standard. This is quite useful from an academic perspective, but totally useless for any practical application. When evaluating the paired-sample, the assumption is that random chance will correctly classify 50\% of the companies as bankrupt or not, and any model that exceeds this is doing better than chance. In the real world, of the 10,000 companies that trade on exchanges, only 600 will go bankrupt - this is a 6\% failure rate, so any model should do better than $94 \%$ accuracy, not 50\%. Some companies might be eligible for bankruptcy, but choose not to file. They might instead threaten to file, and negotiate concessions from creditors. If this company was classified as bankrupt, would that be a correct or incorrect prediction? The classic evaluation model would classify that as a miss, but is it really? This paper addresses the shortcomings of bankruptcy prediction evaluation models and suggests that bankruptcy is better represented as a continuum, rather than a dichotomous situation.
\end{abstract}

\section{INTRODUCTION}

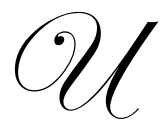

sing financial statement information to predict bankruptcy has been a popular academic topic since Altman's (1968) paper. Beaver published somewhat earlier $(1966,1968)$ but did not focus on bankruptcy; rather financial distress and insolvency (close cousins).

The concept of predicting bankruptcy was not entirely new, even at that time, but the application by Altman of a more sophisticated statistical technique (multiple discriminant analysis (MDA)) caught the academic community's attention. Since then the bankruptcy prediction literature has become voluminous, some utilizing very advanced mathematical techniques.

When bankruptcy prediction studies are subject to replication, the results are not nearly as good as originally achieved (see Platt \& Platt (1990) for a comparison of the models' predictive abilities). The models developed do not stand the test of "robustness." This could be caused by a number of factors. One reason might be that the statistical models tend to use matched pairs of bankrupt and non-bankrupt companies. The variable data is then used to determine cutoffs (thresholds) to differentiate bankrupt and non-bankrupt companies. The data used to derive the thresholds is year specific, and tends to correctly differentiate companies in the hold-out sample (which are from the same time period). These cutoffs work less well when applied in different time periods (including use in replication studies).

Another reason for the deteriorating accuracy of bankruptcy prediction studies might be the variables selected to be incorporated into the model. Starting with Beaver, most research has used variables that were selected based on prevalence and popularity in the literature. Stemming mostly from being related to or thought to be indicative of liquidity, and liquidity being synonymous with solvency, these variables have been used with minor additions, deletions and adjustments.

Altman (1968) started with a very large set of financial statement variables then winnowed them down using MDA based on the variables' contribution to differentiating bankrupt and non-bankrupt companies. Altman 
(and pretty much all papers that followed) selected variables without the benefit of the theoretical development of what a bankrupt company should look like. Necessarily, there needs to be a discussion of what bankruptcy is and what it means, and then develop the set of financial statement variables that would display this. Without this hard look at what a bankrupt company would look like, it is not surprising that bankruptcy prediction models do not stand the test of time.

A major fallacy of these prediction models is the manner in which success is defined - they are academically nuanced in a practical setting. In these studies, it is known in advance which companies are bankrupt and then these bankrupt companies are matched with known non-bankrupt companies from the same time period. A model that predicts better than $50 \%$ (the assumed rate of chance) is thought to out-perform random guessing. This is not the case. A better standard of excellence would be to say that if there were 10,000 publicly traded companies in that time period and 600 went bankrupt, based on chance, $6 \%$ of the companies go bankrupt. Given the opportunity to select whether a company is bankrupt or not from a list of all companies, selecting not-bankrupt would be correct 94\% of the time. A model needs to outperform this standard, not the contrived matched-pair 50\% prediction level, since any practical use of the prediction model would be applied in the 10,000/600 environment. Testing should include random samples drawn from a list of all public companies.

Any practical application involves taking a company and making a prediction of whether they will go bankrupt. In the 1960s (and perhaps 70s as well) bankruptcy was a last result, so the dichotomous classification test would have been more appropriate in that time frame, as companies would use a bankruptcy filing only as a last resort. Over time bankruptcy has taken on strategic importance and lost much of its stigma, so a new evaluation framework must be developed to encompass these changes, as well as to make it useful in a practical setting.

\section{THEORY}

Perhaps one of the major inappropriate leaps made by previous research was equating bankruptcy with liquidity (lack of) and insolvency. Bankruptcy comprises two major types: Chapter 7 (liquidation) and Chapter 11 (reorganization). Liquidity and insolvency would appear to be closely related; however bankruptcy is not synonymous with liquidity or with insolvency. Payne and Hogg (1994) quote from the transcript of the bankruptcy case of Johns-Manville: "The court noted that there is no insolvency requirement for Chapter 11 filings; the point of the reorganization Chapter is to provide the debtor with an automatic stay so that he has time to formulate a plan to restore the profitability of the business." (p23)

Insolvency could lead to bankruptcy, but because a company has filed for bankruptcy does not mean that they are insolvent. Likewise, there is no requirement that the insolvent company file for bankruptcy. They may try to solve their financial problems without resorting to bankruptcy court. Therefore, liquidity ratios may be poor differentiators of the solvent, bankrupt company, and while models might predict a company is bankrupt when the company did not file, the model might be accurate in profiling the company despite the lack of a bankruptcy petition.

Filing for bankruptcy has many costs and certain benefits. Some of the costs include stigma, filing fees, professional fees, higher cost of capital, possible loss of employees, deteriorating morale and potential stock market reaction. On the benefit side, the company gets temporary protection from creditors, possible voiding of certain contracts including union agreements, as well as other benefits (see Payne \& Hogg (1994) for a thorough review of the costs and benefits).

Bankruptcy is a legal condition where a company has petitioned the federal court (the bankruptcy court) under Chapter 7 (liquidation) or Chapter 11 (reorganization) (other possible Chapters are ignored, since Chapters 7 and 11 are the most prevalent). A trustee is then appointed and creditors (who tend to stand to lose all or a portion of the money owed, preferences, rights, or at the very least, must now wait an extended period for payment) are given a chance to object to the filing. The trustee then has to decide whether to grant the petition or not. 
While insolvency is not a precondition for bankruptcy, a company must answer the question of why they need protection from creditors (in a Chapter 11 filing). An apparently solvent company has to document that there is something missing from the financial statements that would render it insolvent at some future point. This might be the potential loss of a lawsuit, an unrecorded contingent liability or some other significant, dire matter. A filing based on the desire to negate a union contract would not be granted.

Therefore, there can be two groups of bankrupt companies - those that demonstrate insolvency and those that are not insolvent, but can document potential insolvency. For those companies not presently insolvent, bankruptcy prediction using financial statement variables is difficult because by definition the potential insolvencycreating event is not reflected in the financial statements. Operationalizing variables to differentiate these companies might rely on narrative information contained in the footnotes to the financial statements or perhaps the opinion.

To evaluate any model, the first and most important question is "what is a correct prediction?" and the complimentary "what is an incorrect prediction?" Using the dichotomous classification test it would seem to be simple to evaluate whether a prediction was correct or not, based on the prediction and the outcome (see Figure 1).

Figure 1

\begin{tabular}{|c|c|c|}
\hline \multicolumn{2}{|c|}{ Prediction Matrix } \\
\hline Prediction Outcome & Bankrupt & Not Bankrupt \\
\hline Filed & Correct & Correct \\
\hline Did Not File & Incorrect & Correct \\
\hline
\end{tabular}

Despite, the convenience with which that evaluation model can be applied to research, it is not efficacious in determining which models are effective at predicting bankruptcy. The population who would use a bankruptcy prediction model for anything other academic research would encompass, largely, investors and creditors. Because bankruptcy has costs, they want to gauge whether their equity or debt investments would be at risk. At the time they are making their assessments, they have no idea of the population of bankrupt companies. All companies that they are considering are a candidate for bankruptcy. In academic research, the individual making the prediction would know a priori that half the companies are bankrupt and half are not. No such knowledge is available in a practical setting.

The concept of bankruptcy being a dichotomous situation is spurious. It is true that a company has either filed for bankruptcy or has not filed, but that misses the point of the research. Any company that has the ability to avail themselves of a bankruptcy filing stands to have the potential to receive creditor concessions on a voluntary basis whether they file or not. The evaluation model must take this into account to be useful in a non-academic setting.

\section{Literature Review}

The dichotomous classification test has been the standard model for use in evaluating bankruptcy prediction models. See Figure 2 for a list of the papers that used the dichotomous classification test. 
Figure 2

Papers Utilizing the Dichotomous Classification Test

Altman, Edward (1968)

Aziz, Abdul, David C. Emanuel, Gerald H. Lawson (1988)

Aziz, Abdul, Gerald H. Lawson (1989)

Beaver, William H. (1966)

Beaver, William H. (1968)

Camp, Woody (1993)

Carcello, Joseph V., Dana R. Hermanson, Fenwick H. Huss (1995)

Casey, Cornelius J., Norman J. Bartczak (1984)

Casey, Cornelius, Norman Bartczak (1985)

Deakin, Edward B. (1972)

Dugan, Michael T., Christine V. Zavgren (1988)

Edmister, Robert O. (1972)

Foster, Benjamin P., Terry J. Ward (1997)

Gentry, James A., Paul Newbold, David T. Whitford (1985)

Gilbert, Lisa R., Krishnagopal Menon, Kenneth B. Schwartz (1990)

Grice, John Stephen, Robert W. Ingram (2001)

Kim, Choong Nyoung, Raymond McLeod Jr. (1999)

Mensah, Yaw M. (1984)

Morris, Richard (1998)

Platt, Harlan D., Marjorie B. Platt (1990)

Ricci, Cecilia Wagner (2003)

Shah, Jaymeen R., Mirza B. Murtaza (2000)

Sung, tae Kyung, Namsik Chang, Gunhee Lee (1999)

Wilcox, James W. (1971)

The typical application of the dichotomous classification test is to match known bankrupt companies with non-bankrupt companies from the same standard industry classification code and of similar asset size. From the population of these matched pairs, a number of companies are put into a hold-out sample, the rest are subjected to the model.

The model classifies each of the companies as bankrupt or not, then a comparison to the actual state is done, and error percentages calculated. The model is then applied to the hold out sample to determine error percentages. A comparison is then done among the sample, the holdout sample and the assumed rate of chance $(50 \%)$.

\section{FUTURE RESEARCH}

The basic, underlying, inescapable problem with the current dichotomous evaluation model is that bankruptcy can no longer be thought of as a dichotomous variable. The purpose of the Chapter 11 bankruptcy petition is to give a company time to reorganize and return to profitability. This same end could potentially be achieved by the company threatening creditors with the possibility of having to file a bankruptcy petition. If the company can get the creditors to accept concessions, then the company might attain all of the benefits they would have received from a bankruptcy petition without having to undertake any of the costs or burdens. 
Given this, the model has to take into account what previously would have been considered errors:

- the company meets the criteria for a filing but chooses not to

- $\quad$ the company is not insolvent but chooses to file

Incorporating this into a model is not easy. The beauty of the dichotomous classification test was that it was simple and direct to apply. The failing was that it has no value in a contemporary, practical setting. Developing a useful evaluation model will involve creating a continuum of a bankrupt company, with the difficulty them becoming assessing how well the model did. This will be a topic for future research.

\section{CONCLUSION}

The current dichotomous classification test, the standard used in evaluating bankruptcy prediction research, fails to correctly classify situations that would be very important to users outside of an academic environment. A company might be eligible to file for bankruptcy, but chooses not to, using the potential as leverage to obtain concessions from creditors. A prediction model might have predicted the company to be bankrupt and since there was no filing, this would be counted as an error. However, the company used the potential of filing as a way to negotiate every benefit they might have gotten from a filing, and therefore the model should be considered to have correctly classified this.

Bankruptcy is more of a continuum than a dichotomous variable. A new way of evaluating predictions has to be developed and applied to models to make them useful in a practical setting. Creditors, lenders and potential investors do not sit down with two lists of companies; one list bankrupt and one not, jumble up the companies and then select the non-bankrupt. Real-world use starts with a list of companies without a priori knowledge of how many are/will be bankrupt and then the model is asked to classify each. This is how users will apply the model, and this is how the evaluation of the model should proceed.

\section{REFERENCES}

1. Altman, Edward (1968) "Financial Ratios, Discriminant Analysis and the Prediction of Corporate Bankruptcy," The Journal of Finance, September, pp $589-609$.

2. Aziz, Abdul, David C. Emanuel, Gerald H. Lawson (1988) "Bankruptcy Prediction An Investigation of Cash Flow Based Models,” Journal of Management Studies, September, pp 419 - 437

3. Aziz, Abdul, Gerald H. Lawson (1989) "Cash Flow Reporting and Financial Distress Models: testing of Hypothesis," Financial Management, spring, pp $55-63$.

4. Beaver, William H. (1966) "Financial Ratios as Predictors of Failure," Empirical Research in Accounting: Selected Studies, 1966, pp $71-111$.

5. Beaver, William H. (1968) "Alternative Accounting Measures as Predictors of Failure," The Accounting Review, January, pp $113-122$.

6. Camp, Woody (1993) “A Manager's Role in Bankruptcy,” Journal of Property Management, May/June, pp $16-19$.

7. Carcello, Joseph V., Dana R. Hermanson, Fenwick H. Huss (1995) "Temporal Changes in BankruptcyRelated Reporting," Auditing, fall, start p133.

8. Casey, Cornelius J., Norman J. Bartczak (1984) “Cash Flow - It's Not the Bottom Line," Harvard Business Review, July-August, pp $61-66$.

9. $\quad$ Casey, Cornelius, Norman Bartczak (1985) "Using Operating Cash Flow Data to Predict Financial Distress: Some Extensions," Journal of Accounting Research, spring, pp $384-401$.

10. Deakin, Edward B. (1972) “A Discriminant Analysis of Predictors of Business Failure," Journal of Accounting Research, spring, pp $167-179$.

11. Dugan, Michael T., Christine V. Zavgren (1988) "Bankruptcy Prediction Research: A Valuable Instructional Tool," Issues in Accounting Education, pp 48 - 64.

12. Edmister, Robert O. (1972) "An Empirical Test of Financial Ratio Analysis for Small Business Failure Prediction," Journal of Financial and Quantitative Analysis, March pp 1477 - 1493. 
13. Foster, Benjamin P., Terry J. Ward (1997) "Using Cash Flow Trends to Identify Risks of Bankruptcy,” The CPA Journal, September, pp $60-61$.

14. Gentry, James A., Paul Newbold, David T. Whitford (1985) "Classifying Bankrupt Firms with Funds Flow Components," Journal of Accounting Research, spring, pp $146-160$.

15. Gilbert, Lisa R., Krishnagopal Menon, Kenneth B. Schwartz (1990) "Predicting Bankruptcy for Firms in Financial Distress," Journal of Business Finance \& Accounting, spring, pp $161-171$.

16. Grice, John Stephen, Robert W. Ingram (2001) "Tests of the Generalizability of Altman's Bankruptcy Prediction Model," Journal of Business Research, August, pp 1 - 13.

17. Kim, Choong Nyoung, Raymond McLeod Jr. (1999) "Expert, Linear Models, and Nonlinear Models of Expert Decision Making in Bankruptcy Prediction: A Lens Model Analysis," Journal of Management Information Systems, summer, pp 189 - 206.

18. Mensah, Yaw M. (1984) "An Examination of the Stationarity of Multivariate Bankruptcy Prediction Models: A Methodological Study," Journal of Accounting Research, spring, pp 380 - 395.

19. Morris, Richard (1998) "Bankruptcy Prediction Models: Just How Useful Are They?" Credit Management, May, pp $43-45$.

20. Payne, Dinah, Michael Hogg (1994) "Three Perspectives of Chapter 11: Legal, Managerial and Moral," Journal of Business Ethics, January, pp 21 - 30.

21. Platt, Harlan D., Marjorie B. Platt (1990) "Development of a Class of Stable Predictive Variables: The Case of Bankruptcy Prediction," Journal of Business Finance \& Accounting, spring, pp $31-51$.

22. Ricci, Cecilia Wagner (2003) "Bankruptcy Prediction: The Case of the CLECS," Mid-American Journal of Business, spring, start page 71.

23. Shah, Jaymeen R., Mirza B. Murtaza (2000) "A Neural Network Based Clustering Procedure for Bankruptcy Prediction,” American Business Review, June, pp 80 - 86.

24. Sung, tae Kyung, Namsik Chang, Gunhee Lee (1999) "Dynamics of Modeling in Data Mining: Interpretive Approach to Bankruptcy Prediction," Journal of Management Information Systems, summer, pp 63 - 85.

25. Wilcox, James W. (1971) "A Simple Theory of Financial Ratios as Predictors of Failure," Journal of Accounting Research, autumn, pp $389-395$. 